\title{
Native isolates and the effect of aviary litter on the pathogenicity and virulence of entomopathogenic nematodes for the control of the lesser mealworm, Alphitobius diaperinus (Panzer) (Coleoptera: Tenebrionidae)
}

\section{Isolados nativos e efeito da cama de aviário na patogenicidade e virulência de nematoides entomopatogênicos visando o controle do cascudinho de aviário, Alphitobius diaperinus (Panzer) (Coleoptera: Tenebrionidae)}

\author{
Thiago Augusto Paes Fernandes ${ }^{1 *}$; Matheus Corseti Marcomini2; \\ Fabio Pinhatari Ferreira3; Bruna Aparecida Guide ${ }^{4}$; Viviane Sandra Alves" \\ Pedro Manoel Oliveira Janeiro Neves ${ }^{6}$
}

\section{Highlights}

Selection test with 14 native isolates from Brazil were undertaken.

The optimal concentration of NEPs were defined.

Effect of poultry litter on the virulence of nematodes was determined.

\footnotetext{
Abstract

Lesser mealworms cause great damage to poultry. Its control is difficult because of the insect's habit of living in the middle of the aviary bed. However, entomopathogenic nematodes (NEPs) can be an effective control of these insects, as they are indicated against pests that live or pass a phase in the soil. The objective of this study was to select native isolates of entomopathogenic nematodes and to evaluate the

1 Biólogo, M.e em Agronomia, Universidade Estadual de Londrina, UEL, Londrina, PR, Brasil. E-mail: thiagouenp@ gmail.com

2 Eng ${ }^{\circ}$ Agr $^{\circ}$, Discente Curso de Mestrado, Programa de Pós-Graduação em Agronomia, UEL, Londrina, PR, Brasil. E-mail: matheusmarcomini11@outlook.com

3 Eng ${ }^{\circ}$ Agr ${ }^{\circ}$, Londrina, PR, Brasil. E-mail: seefloydplay@hotmail.com

4 Profa ${ }^{\text {Dra}}$, Departamento de Agronomia, Faculdade Pitágoras, Londrina, PR, Brasil. E-mail: bruhguide@gmail.com

5 Profa ${ }^{a}{ }^{a}$, Departamento de Biologia, Universidade Estadual do Norte do Paraná, UENP, Cornélio Procópio, PR, Brasil. E-mail: vivialves@uenp.edu.br

6 Prof. Dr., Departamento de Agronomia, UEL, Londrina, PR, Brasil. E-mail: pedroneves@uel.br

* Author for correspondence
}

Received: Sept. 03, 2019 - Approved: Oct. 26, 2020 
effect of poultry litter on its pathogenicity and virulence, with the aim of using these to control the lesser mealworm in poultry. Fourteen native isolates and two non-native isolates were used in the selection test, and the three most virulent isolates were used in the concentration test $(10,20,40$, and 50 infective juveniles (JIs) per $\mathrm{cm}^{2}$ ). Both experiments were performed in a completely randomized design, with the data from the selection test being submitted to the Scott-Knott mean test $(P \leq 0.05)$ and the concentration test to regression analysis. The effect of poultry litter (new and old) was evaluated on Steinernema feltiae (IBCB-n 47), S. carpocapsae (All), and Heterorhabditis amazonensis (UEL 08), and the test was conducted in $2 \times 3$ factorial (two types of litter and three isolates) design, and the data were subjected to Tukey's mean test $(P \leq 0.05)$. In the selection test with adult hosts, the three most virulent isolates were $H$. amazonensis (UEL 07), H. amazonensis (RSC 05), and S. carpocapsae (all) with $76.5 \%, 73.5 \%$, and $70 \%$ mortality, respectively. For larvae, the isolates Heterorhabditis sp. (NEPET 11), S. feltiae (IBCB-n 47), H. amazonensis (UEL 07), Heterorhabditis sp. (IBCB-n40), and H. amazonensis (UEL 08) were the most virulent and differed statistically from the control. In the concentration test, the highest mortality in adults (98\%) and larvae (98\%) was observed with S. feltiae at concentrations of $30 \mathrm{JIs} / \mathrm{cm}^{2}$ and $50 \mathrm{Jls} / \mathrm{cm}^{2}$, respectively, and the native isolate evaluated (UEL 07) presented the worst performance. Regarding the effect of litter, it was observed that S. feltiae (IBCB-n 47) and S. carpocapsae (All) caused the highest mortalities, both in new litter $(60.7 \%$ and $58.7 \%$, respectively) and in old litter ( $80.0 \%$ and $74.7 \%$, respectively), which were higher than that observed for the native isolate (UEL 08).

Key words: Biological control. Heterorhabditis. Steinernema.

\section{Resumo}

O cascudinho causa grande prejuízo para a avicultura. Seu controle é dificultado, devido ao hábito do inseto de viver em meio a cama de aviário. Por outro lado, os nematoides entomopatogênicos (NEPs) podem ser uma alternativa no controle destes insetos, pois são indicados contra pragas que vivem ou passam uma fase no solo. Desta forma objetivou-se selecionar isolados nativos de NEPs e avaliar o efeito da cama de aviário na sua patogenicidade e virulência, visando o controle do cascudinho de aviário. Foram utilizados 14 isolados nativos e dois isolados importados no teste de seleção e os três isolados mais virulentos foram utilizados no teste de concentrações $\left(10,20,40,50\right.$ juvenis infectantes $\left.(\mathrm{JIs}) / \mathrm{cm}^{2}\right)$. Ambos experimentos foram realizados em delineamento inteiramente casualizado, sendo que os dados do teste de seleção foram submetidos a teste de média Scott-Knott $(P \leq 0,05)$ e o teste de concentrações à análise de regressão. $O$ efeito da cama de aviário (nova e velha) foi avaliado sobre Steinernema feltiae (IBCB-n 47), Steinernema carpocapse (All), e Heterorhabditis amazonensis (UEL 08), e o ensaio foi conduzido em fatorial $2 \times 3$ (dois tipos de cama e três isolados), e os dados foram submetidos ao teste de médias Tukey $(\mathrm{P} \leq 0,05)$. Observou-se no teste de seleção para adultos, que os três isolados mais virulentos foram Heterorhabditis amazonensis (UEL 07), $H$. amazonensis (RSC 05) e S. carpocapsae (All) com 76,5; 73,5; 70\% mortalidade, respectivamente. Para larvas, os isolados Heterorhabditis sp. (NEPET 11), S. feltiae (IBCB-n 47), H. amazonensis (UEL 07), Heterorhabditis sp. (IBCB-n40) e H. amazonensis (UEL 08) foram os mais virulentos e diferiram estatisticamente. No teste de concentrações, a maior mortalidade em adultos (98\%) e larvas (98\%) foi observada para S. feltiae nas concentrações de $30 \mathrm{JIs} / \mathrm{cm}^{2}$ e $50 \mathrm{JIs} / \mathrm{cm}^{2}$ respectivamente, e o isolado nativo avaliado (UEL 07) foi o que apresentou o pior desempenho. Com relação ao efeito da cama de aviário, observou-se que S. feltiae (IBCB-n 47) e S. carpocapse (All) causaram as maiores mortalidades, tanto em cama nova $(60,7$ e 58,7\%) 
quanto em cama velha (80 e 74,7\%) respectivamente sendo também superiores ao desempenho do isolado nativo (UEL 08).

Palavras-chave: Controle biológico. Heterorhabditis. Steinernema.

\section{Introduction}

The "lesser mealworm", Alphitobius diaperinus (Panzer) (Coleoptera: Tenebrionidae) is a cosmopolitan pest, originally from the African continent (Vaughan, Turner, \& Ruszler, 1984), which uses broiler poultry litter as an economic environment at temperature, collect, shelter, and feed for their development (Japp, Bicho, \& Silva, 2010). However, they destroy poultry litter and harbor several avian pathogens (Axtell \& Arends, 1990), making them one of the main pest insects in poultry farming.

The lesser mealworm can be a vector and reservoir of pathogens such as those that cause the Newcastle disease, Gumboro disease, avian leukosis, and other diseases that cause immunosuppression in birds that can cause death (Despins \& Axtell, 1995). In addition, birds are attracted to consuming both the adult stage and the larvae of this beetle, which decreases the daily rate of feed intake, resulting in considerable weight loss due to damages to the digestive tract caused by the rigidity of the elytron, leaving them even more vulnerable to infections (Japp et al., 2008).

The control of these pests is hampered by the presence of birds in the aviary. In addition, this insect inhabits cracks in the floor, and is often found concentrated below the feeders, drinking fountains, close to the supporting pillars of the buildings, and below the ground, which facilitates reinfection (L. F. A Alves, Rohde, \& Alves, 2005).

Chemical insecticides are commonly used for their control. However, when applied improperly, these can cause environmental problems, accumulate in poultry meat, facilitate the selection of resistant individuals, and can cause poisoning of poultry farmers (Rohde et al., 2006). Thus, it is necessary to look for nonchemical control alternatives that can be used on a commercial scale. Among the alternatives, biological control with entomopathogenic nematodes (NEPs) has been suggested (V. S. Alves, Neves, Alves, Moino, \& Holz, 2012).

NEPs are obligate parasites, with important characteristics such as host specificity, ability to search for the host, virulence, and compatibility with other entomopathogens and chemical pesticides (Fuga, Fernandes, \& Lopes, 2012; Guide, Alves, Fernandes, Ferreira, \& Neves, 2016). In addition, these organisms show symbiotic relationships with bacteria, the main characteristic of the species of the two genera, Heterorhabditis and Steinernema, which are most commonly used in biological control. The majority of species of the genus Heterorhabditis are colonized by bacteria of the genus Photorhabdus, and species of the genus Steinernema, in general, are colonized by bacteria of the genus Xenorhabdus (Forst \& Clarke, 2002). These bacteria when inoculated into the host's hemocele excrete lethal toxins, which cause the death of the host insect within 72 hours (Dolinski \& Moino, 2006)

The species of the genera Heterorhabditis and Steinernema are able to move in the soil through water, a characteristic that should be highlighted in relation to other entomopathogens (Fuga et al., 2012). Lewis, 
Campbell, Griffin, Kaya and Peters (2006) classified these nematodes into two categories based on their search strategy: "cruiser" (tracking) in which, the nematode moves in search of the host, and "ambusher" (ambush), in which, the nematode waits for the insect to ingest it when feeding to penetrate the insect's body. Infection of NEPs occurs mainly through penetration through natural openings (mouth, anus, and spiracles).

Geden, Axtell \& Brooks (1985) found the efficiency of NEPs, especially Steinernema glaseri, S. feltiae, and Heterorhabditis heliothidis, to be high under laboratory conditions. In Brazil, some studies report the extraordinary efficiency of the species $S$. carpocapsae (L. F. A. Alves et al., 2005) and S. arenarium (V. S. Alves et al., 2012). However, in the field, it is important to first consider the use of native species (Dolinski \& Moino, 2006), and avoid the risk of introducing exotics.

Thus, we aimed to select entomopathogenic nematodes that were native to Brazil, compare them with two nonnative species, and evaluate the effect of poultry litter on the pathogenicity and virulence of these species for use in the control of avian mealworm.

\section{Materials and Methods}

Obtaining, multiplying, and storing of NEP isolates

The individuals used in the selection test belonged to the collection maintained at the Laboratory of Pathology and Microbial Control of Insects at the State University of Londrina (UEL), which were derived from nematodes provided by the Laboratory of Entomology and Microbial Control at the State University of Northern Paraná (Cornélio Procópio - PR) and the Instituto Biológico in Campinas, SP (Table 1).

For maintenance and use in the bioassays, they were multiplied in vivo, according to Molina and Lopes (2001), using the last stage of Galleria mellonella L. (Lepidoptera: Pyralidae). 
Table 1

Isolates from entomopathogenic nematodes of the genera Steinernema and Heterorhabditis used in the selection test against larvae and adults of Alphitobius diaperinus under laboratory conditions

\begin{tabular}{lcc}
\hline Isolates & Species & Origin \\
\hline RSC 05 & Heterorhabditis amazonensis & Benjamin Constant - AM - Brazil \\
NEPET11 & Heterorhabditis sp. & Palmeira das Missões - RS - Brazil \\
ALHO-GL & Heterorhabditis sp. & Lavras - MG - Brazil \\
IBCB-n 40 & Heterorhabditis sp. & Tabapuã - SP - Brazil \\
IBCB-n 05 & Heterorhabditis indica & Itapetininga - SP - Brazil \\
IBCB-n 06 & Steinernema brazilense & Porto Murtinho - MT - Brazil \\
IBCB-n 44 & Heterorhabditis sp. & Santa Adélia - SP - Brazil \\
IBCB-n 46 & Heterorhabditis sp. & Santo Antônio de Posse - SP - Brazil \\
JPM 4 & Heterorhabditis sp. & Lavras - MG - Brazil \\
UEL 01 & Heterorhabditis amazonensis & Londrina - PR - Brazil \\
UEL 07 0 Heterorhabditis amazonensis & Londrina - PR - Brazil \\
UEL 08 & Heterorhabditis amazonensis & Londrina - PR - Brazil \\
PAM & Steinernema rarum & Aceguá - RS - Brazil \\
AM163 & Steinernema diaprepesi & Sinop - MT - Brazil \\
All & Steinernema carpocapsae & Florida - USA \\
IBCB-n 47 & Steinernema feltiae & Germany
\end{tabular}

Collection of lesser mealworm and obtaining chicken litter

The population of $A$. diaperinus and the seven month old litter (litter from the fifth batch; old) used in the tests were obtained from a poultry rearing house with soil floor, in the city of Londrina, Paraná (2318'37"S; 5109'46"W). As collections were made with gas, the bed surface was removed from under the base of feeders, where the insect population was more concentrated and was stored in a plastic container. This was kept at $25 \pm 1{ }^{\circ} \mathrm{C}$ in the laboratory from June to October 2018. A 50 $\mathrm{g}$ portion of chicken feed was added to the container for feeding the insects.

The litter from the first batch, i.e., 45 days old litter (new) was collected from the poultry rearing sheds in the Fazenda Escola of the State University of Londrina (UEL), Londrina, PR. The bed was removed manually from the central part of the bay and placed in a $20 \mathrm{~L}$ plastic container. The storage was carried out in the same place and under conditions similar to that described above.

Selection of native isolates of entomopathogenic nematodes that affect Alphitobius diaperinus

For the selection test, 16 NEPs belonging to the genera Heterorhabditis and Steinernema from the entomopathogen bank were used (Table 1). The pathogenicity and virulence in the larvae and adults of $A$. diaperinus were determined following the 
methodology of V. S. Alves et al. (2012) with changes in the larval test.

To test the effect of the NEPs on the adult beetles, each treatment consisted of four repetitions. Each repetition included a Petri dish, $9 \mathrm{~cm}$ in diameter, containing two filter papers at the base, and 15 insects. With the aid of a micropipette, concentrations of 100 juvenile infectious agents (JIs) per $\mathrm{cm}^{2}$ with additional distilled water, totaling $2 \mathrm{~mL}$ of suspension per plate, were applied homogeneously on the paper. The insects were subsequently released into the Petri dish. The control followed the same procedure, but the suspension was replaced with $2 \mathrm{~mL}$ distilled water.

In the larval assay, each of the four replicates was represented by a 12-well cell culture plate. In each well (2.2 cm in diameter) two paper discswere placed followed byasingle larva (in order to avoid cannibalism between them), totaling 12 larvae per repetition. Jls at a concentration of $100 \mathrm{Jls} / \mathrm{cm}^{2}$ were applied to each well along with additional distilled water, totaling $0.18 \mathrm{~mL}$ per well. This was done immediately after the release of the larva in the water channel. In the control, only $0.18 \mathrm{~mL}$ of distilled water was applied to each well.

Tostandardize the tests, a concentration of $100 \mathrm{Jls} / \mathrm{cm}^{2}$ was stipulated. The bioassays were conducted in a random isolated design and kept in an air-conditioned chamber at $25 \pm 1{ }^{\circ} \mathrm{C}$, UR70 $\pm 10 \%$, without photoperiod, and without food. The evaluation took place after five days of exposure of insects to NEPs, after which the dead insects were dissected to confirm if the death was caused by NEP. Analysis of variance and the Scott-Knott media test $(P \leq 0.05)$ were performed using the statistical program SISVAR, version 5.4
(Ferreira, 2011). The nematodes that caused the highest mortality were selected for the concentration tests.

\section{Concentration tests}

Six concentrations of the nematodes $(0$ (control), 10, 20, 30, 40, and $50 \mathrm{Jls} / \mathrm{cm}^{2}$ ) were tested on the larvae and adults. Four replicates for each concentration for adults and for larvae were set up and the same methodology used in the selection test was used.

The data were subjected to regression analysis using the SISVAR statistical program, version 5.4 (Ferreira, 2011). The maximum lethal concentration was then estimated from the derived regression equation, determining the selected value in the evaluated range.

\section{Evaluation of density and $\mathrm{pH}$}

The density of the poultry litter substrate was evaluated to determine whether this interfered with the action of the NEPs. For this, we weighed $1 \mathrm{~L}$ of each batch of litter (new and old) and used the results is based on the quotient of both.

The method used to determine the $\mathrm{pH}$ of the litter was the same as for soils (Claessen, Barreto, Paula, \& Duarte, 1997); three repetitions were performed for each lot. Each repetition included $10 \mathrm{~cm}^{3}$ of the bed taken in an Erlenmeyer flask (10 $\mathrm{cm}^{3}$ of bed) to which $25 \mathrm{~mL}$ of $0.01 \mathrm{M} \mathrm{CaCl}_{2}$ solution was added, stirred for $15 \mathrm{~min}$ at $250 \mathrm{rpm}$, and kept to rest for $30 \mathrm{~min}$ before the $\mathrm{pH}$ was determined. The potentiometer was first calibrated with buffer solutions of $\mathrm{pH} 7.0$ and $\mathrm{pH} 4.0$ before determining the $\mathrm{pH}$ of the samples. 
Evaluation of the effect of bed on the pathogenicity and virulence of NEPS

The non-native species, $S$. feltiae and $S$. carpocapsae, and the native isolate $H$. amazonensis UEL 08 were evaluated, with a view to low performance or UEL 07 without test testing. The Jls were applied to the new and old litter, and a $3 \times 2$ factorial design was used for this evaluation (three NEPs and two types of bedding). In all procedures, a concentration of $100 \mathrm{Jls} / \mathrm{cm}^{2}$ was used, and the control was treated with water alone. For each treatment, 10 repetitions were made with 15 adult insects, totaling 150 insects per treatment. Each repetition corresponded to a plastic pot with a metallic mesh glued to the lid to ensure aeration. The volume of the pot was approximately $2 \mathrm{~L}$, with a $12 \mathrm{~cm}$ diameter base, and 113,097 $\mathrm{cm}^{2}$ area. Each pot was filled to a height of $1.25 \mathrm{~cm}$ with the litter, which corresponded to $50 \mathrm{~g}$ for the first batch litter (lighter) and $100 \mathrm{~g}$ for the fifth batch litter (heavier). These were then moistened with 45 $\mathrm{mL}$ of tap water.

The pots were kept in an air-conditioned chamber at $25 \pm 1{ }^{\circ} \mathrm{C}$ and without photoperiod. The evaluation was performed after five days, when the numbers of dead and live insects were noted to estimate the percentage of mortality. The dead insects were then dissected to confirm the mortality from NEPs.

The data were subjected to normality and homoscedasticity tests, following which the medians were compared by the Tukey test using the SISVAR statistical program $(P \leq 0.05)$ (Ferreira, 2011).

\section{Results and Discussion}

Selection of native isolates of entomopathogenic nematodes that affect Alphitobius diaperinus

Adults

It was found that all tested nematodes demonstrated pathogenicity in adults, with the exception of S. brazilense (IBCB-n 06), which did not differ from the control. A large variation in virulence was also observed, with mortality rates between $3.5 \%$ and $76.5 \%$. The native species Heterorhabditis sp. (UEL 07) and $H$. amazonensis (RSC 05), as also the isolate $S$. carpocapsae (All), differed from the others and showed mortality rates above $66 \%$ (Table 2 ). 


\section{Table 2}

Mortality (\%) of Alphitobius diaperinus adults caused by entomopathogenic nematodes (Steinernema spp. and Heterorhabditis spp.) under laboratory conditions (Temperature: $25 \pm 1{ }^{\circ} \mathrm{C}$, UR: $70 \pm 10 \%$, and without photoperiod)

\begin{tabular}{lcc} 
Species (Treatments) & Isolates & Mortality (Average \%) \\
\hline Heterorhabditis amazonensis & UEL 07 & $76.50 \pm 1.81 \mathrm{a}$ \\
Heterorhabditis amazonensis & RSC 05 & $73.50 \pm 5.47 \mathrm{a}$ \\
Steinernema carpocapsae & All & $70.00 \pm 1.55 \mathrm{a}$ \\
Steinernema feltiae & IBCB-n 47 & $56.75 \pm 3.87 \mathrm{~b}$ \\
\hline Heterorhabditis sp. & IBCB-n 40 & $45.00 \pm 5.51 \mathrm{~b}$ \\
Heterorhabditis sp. & ALHO-GL & $45.00 \pm 2.80 \mathrm{~b}$ \\
\hline Heterorhabditis amazonensis & UEL 08 & $33.25 \pm 2.37 \mathrm{c}$ \\
Steinernema diaprepesi & AM 163 & $31.75 \pm 5.27 \mathrm{c}$ \\
Heterorhabditis indica & IBCB-n 05 & $31.50 \pm 1.34 \mathrm{c}$ \\
Heterorhabditis amazonensis & UEL 01 & $31.00 \pm 3.81 \mathrm{c}$ \\
\hline Heterorhabditis sp. & IBCB-n 44 & $30.00 \pm 3.81 \mathrm{c}$ \\
Heterorhabditis sp. & JPM4 & $25.00 \pm 5.51 \mathrm{c}$ \\
Heterorhabditis sp. & IBCB-n 46 & $23.25 \pm 5.57 \mathrm{c}$ \\
Steinernema rarum & PAM & $21.75 \pm 9.71 \mathrm{c}$ \\
Heterorhabditis sp. & NEPET11 & $21.75 \pm 6.61 \mathrm{c}$ \\
Steinernema brazilense & IBCB-n 06 & $3.50 \pm 1.81 \mathrm{~d}$ \\
Control & - & $0.00 \pm 0.00 \mathrm{~d}$ \\
C.V. & & 22.44
\end{tabular}

* Averages followed by the same lowercase letter in the column did not differ significantly by the Scott-Knott test $(\mathrm{P} \leq$ 0.05).

It is possible to justify the low mortality observed for S. brazilense (3.50\%) and $S$. diaprepesi (31.75\%) as these nematodes have body lengths greater than $1 \mathrm{~mm}$, which may hinder its penetration into the host body via natural openings (Román \& Figueroa, 1994; Nguyen, Ginarte, Leite, Santos, \& Harakava, 2010).

We also noted that there was a significant variation in the virulence of the nematodes that were tested. This can be attributed to several factors. Li, Liu, Lewis and Tarasco (2016) reported that larvae of Tenebrio molitor L. (Coleoptera: Tenebrionidae), belonging to the same beetle family, when infected by NEPs, starts to produce detoxifying enzymes that can delay or inhibit or reduce the effect of these NEPs. However, this can vary depending on the nematode used and the species of insect it infects. Grewal, Nardo and Aguillera (2001) has highlighted the behavioral resources of both hosts and NEPs that affect the process of parasitism and the infection of the host, and these include, mainly, the ability to move and search for the host, ability to penetrate and provoke the infection, and ability to overcome defenses of the immune system (Lewis et al., 2006). 
The authors Geden et al. (1985) and Szalanski, Palmer, Mckay and Steelman (2004) have pointed out that there may be variation in the virulence observed for the same species (S. feltiae and S. carpocapsae) on lesser mealworm. In this study, we observed a mortality rate of $70 \%$ in the adults infected by S. carpocapsae (all), which was similar to the value reported by Szalanski et al. (2004) for S. carpocapsae (UK, Kapow, Agriotos, Mexicano, Mexicano/Breton), but was well above that observed by L. F. A. Alves et al. (2005) and V. S. Alves et al. (2012) for the same species

In the present study, variations within the same species was also observed for $H$. amazonensis UEL 01, UEL 08, and UEL 07, for which we recorded adult mortality rates of $31 \%, 33.25 \%$, and $76.5 \%$, respectively, highlighting the importance of conducting resource selection tests.

Larvae

In general, when comparing larval mortality (Table 3 ) with adults (Table 2), there is a greater susceptibility of larvae to infections, with 12 out of 16 isolates showing more than $60 \%$ of mortality confirmed by NEPs. This greater susceptibility was also observed by Geden et al. (1985), Szalanski et al. (2004), and L. F. A. Alves et al. (2005). Several factors can justify this result-larvae show higher activity than adults, facilitating their encounter with the NEP; the larvae also show less rigidity when compared to adults, which facilitates the penetration of the Jls; in addition, during ecdysis, the higher exposure of the host beetle makes them more susceptible to infection by larvae.

Native individuals Heterorhabditis sp. (NEPET 11), Heterorhabditis sp. (UEL 07), Heterorhabditis sp. (IBCB-n 40), and Heterorhabditis sp. (UEL 08) were more virulent in larvae compared to the others showing $100 \%, 93.7 \%, 85.5 \%$, and $85.5 \%$ mortality, respectively (Table 3 ). Among the non-native species, S. feltiae (IBCB-n 47), showed the highest mortality $(96.0 \%)$ in larvae.

Although $H$. amazonensis UEL 08 and NEPET 11 presented inferior virulence in the adult stage (21.75\% and $33.25 \%$, respectively) (Table 2), in the larvae, they were found to show high virulence. Therefore, it is suggested that these are not discarded for future tests, as they have been found effective in the control of the larval phase, and can interrupt the insertion cycle and consequently control population growth of the pest. Further, S. diaprepesi, and Heterorhabditis sp. (GL) also demonstrated opposite effects on larvae and adults (Table 3 ).

The mortality results observed in this study for S. rarum (MAP) were lower (27.25\%) than those observed by Del Valle et al. (2016), who obtained values of up to $72.7 \%$. Szalanski et al. (2004), studied the effect of different types of $S$. feltiae and $S$. carpocapsae on rat worm larvae, and reported mortalities ranging from $0 \%$ to $100 \%$ and from $16.8 \%$ to $93.2 \%$, respectively. 


\section{Table 3}

Mortality (\%) of Alphitobius diaperinus larvae caused by entomopathogenic nematodes (Steinernema spp. and Heterorhabditis spp.) under laboratory conditions (Temperature: $25 \pm 1{ }^{\circ} \mathrm{C}$, UR: $70 \pm 10 \%$, and without photoperiod)

$\begin{array}{lcc}\text { Species (Treatments) } & \text { Isolates } & \text { Mortality (\%) } \\ \text { Heterorhabditis sp. } & \text { NEPET11 } & 100.00 \pm 0.00 \mathrm{a} \\ \text { Heterorhabditis amazonensis } & \text { UEL 07 } & 93.75 \pm 3.62 \mathrm{a} \\ \text { Steinernema feltiae } & \text { IBCB-n 47 } & 96.00 \pm 2.07 \mathrm{a} \\ \text { Heterorhabditis sp. } & \text { IBCB-n 40 } & 85.50 \pm 14.06 \mathrm{a} \\ \text { Heterorhabditis amazonensis } & \text { UEL 08 } & 85.50 \pm 3.66 \mathrm{a} \\ \text { Heterorhabditis sp. } & \text { IBCB-n 44 } & 79.00 \pm 2.07 \mathrm{~b} \\ \text { Steinernema carpocapsae } & \text { All } & 77.00 \pm 14.03 \mathrm{~b} \\ \text { Heterorhabditis amazonensis } & \text { RSC 05 } & 72.75 \pm 10.27 \mathrm{~b} \\ \text { Heterorhabditis amazonensis } & \text { UEL 01 } & 70.75 \pm 4.79 \mathrm{~b} \\ \text { Heterorhabditis indica } & \text { IBCB-n 05 } & 68.75 \pm 9.63 \mathrm{~b} \\ \text { Heterorhabditis sp. } & \text { JPM4 } & 60.25 \pm 4.04 \mathrm{~b} \\ \text { Heterorhabditis sp. } & \text { IBCB-n 46 } & 39.75 \pm 2.01 \mathrm{c} \\ \text { Steinernema rarum } & \text { PAM } & 27.25 \pm 7.80 \mathrm{~d} \\ \text { Heterorhabditis sp. } & \text { ALHO-GL } & 19.00 \pm 7.95 \mathrm{~d} \\ \text { Steinernema diaprepesi } & \text { AM 163 } & 16.75 \pm 4.30 \mathrm{~d} \\ \text { Steinernema brazilense } & \text { IBCB-n 06 } & 0.00 \pm 0.00 \mathrm{e} \\ \text { Control } & - & 0.00 \pm 0.00 \mathrm{e} \\ \text { C.V. } & & 22.44\end{array}$

* Averages followed by the same lowercase letter in the column did not differ significantly by the Scott-Knott test $(\mathrm{P} \leq$ 0.05).

\section{Concentration test using adult host}

Based on the results from the selection tests, the non-native species S. feltiae, S. carpocapsae and the native $H$. amazonensis (UEL 07), were found to be most effective on adults, and for farmers preferring not to use chemical controls, these species show good multiplication capacity in the host (Rahoo, Mukhtar, Gowen, Rahoo, \& Abro, 2017), which can guarantee their persistence in the environment.
The three individuals caused mortality in adults of $A$. diaperinus in all evaluated concentrations. From these results, we identified the best concentrations for use for each of the isolates.

Adult mortality from the application of S. carpocapsae (All) varied between $58.0 \%$ and $90.0 \%$ (Figure 1), where an application in the highest concentration $\left(50.0 \mathrm{JIs} / \mathrm{cm}^{2}\right)$ caused a higher mortality. In tests with S. feltiae (IBCB-n 47), mortality varied between $56.0 \%$ and $98.0 \%$ (Figure 2); the highest mortality was observed for concentrations of 30 and $40 \mathrm{JIs} / \mathrm{cm}^{2}$. The 
application of $\mathrm{H}$. amazonensis (UEL 07) showed a variation in adult mortality between $20.0 \%$ and $46.0 \%$, where the concentration of $40 \mathrm{JIs} /$ $\mathrm{cm}^{2}$ resulted in the maximum control.

Further, it was noted that the cascade mortality showed little variation between the concentration of $20 \mathrm{Jls} / \mathrm{cm}^{2}$ for the isolate $S$. carpocapsae and $30 \mathrm{JIs} / \mathrm{cm}^{2}$ for the isolate S. feltiae. According to Gaugler, Wang and Campbell (1994), these isolates can reach the minimum number of NEPs needed to infect and cause the death of the host.

B

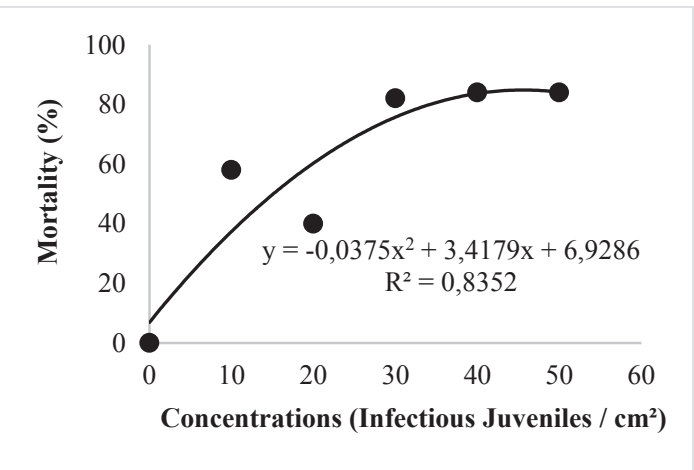

A

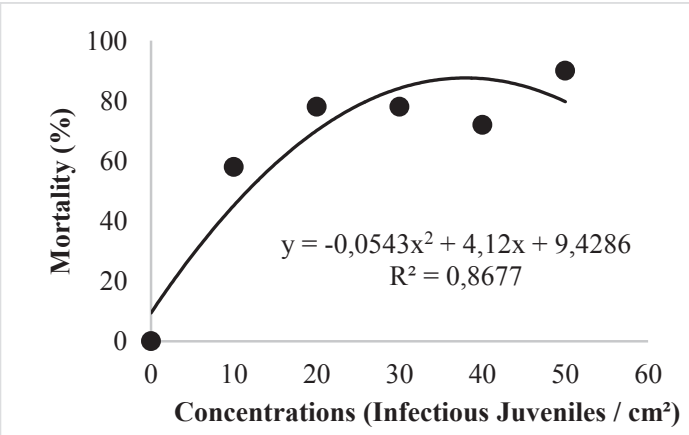

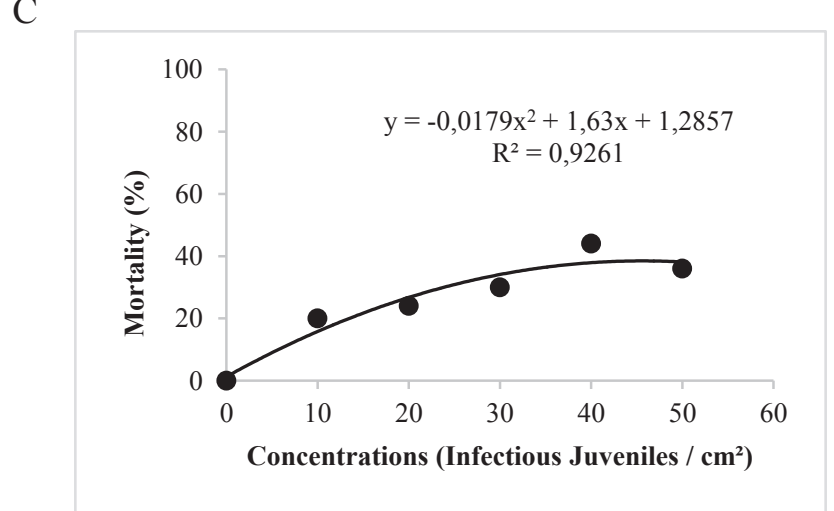

Figure 1. Mortality regression curve (\%) of adults of Alphitobius diaperinus as a function of entomopathogenic nematode (NEP) concentrations (Jls/cm²): A) Steinernema carpocapsae (All), B) Steinernema feltiae (IBCB-n 47), and C) Heterorhabditis amazonensis (UEL 07). Maximum estimated mortality: A) $87.6 \%$ with application of $37.95 \mathrm{Jls} / \mathrm{cm}^{2}$; B) $84.81 \%$ with application of $45.57 \mathrm{Jls} / \mathrm{cm}^{2}$; and C) $38.48 \%$ with application of $45.64 \mathrm{Jls} / \mathrm{cm}^{2}$.

We observed that the effect of $H$. amazonensis (UEL 07) we observed that the effect of $H$. amazonensis (UEL 07) was reduced when applied at low concentrations, mainly at 10 and $20 \mathrm{Jls} / \mathrm{cm}^{2}$ (Figure 1), mainly at 10 and $20 \mathrm{Jls} / \mathrm{cm}^{2}$ concentrations (Figure 1). When comparing these results with the selection test where concentrations of $100 \mathrm{Jls} / \mathrm{cm}^{2}$ were used, the latter showed better efficiency (76.5\% of average mortality). Rahoo et al. (2017) indicated that the probability of being infected may be related to the number of nematodes 
applied, since the application of higher rates most often results in higher mortality.

\section{Concentration test using larvae as host}

We evaluated the effect of various concentrations on the mortality of larvae, and the results were similar to that observed for the adults. As in the previous test, all isolates caused mortality even at the lowest concentration. The results for larvae compared to adults (Figure 1) reinforce the idea that $A$. diaperinus larvae may be more susceptible to infection by NEPs (Figure 2).

A

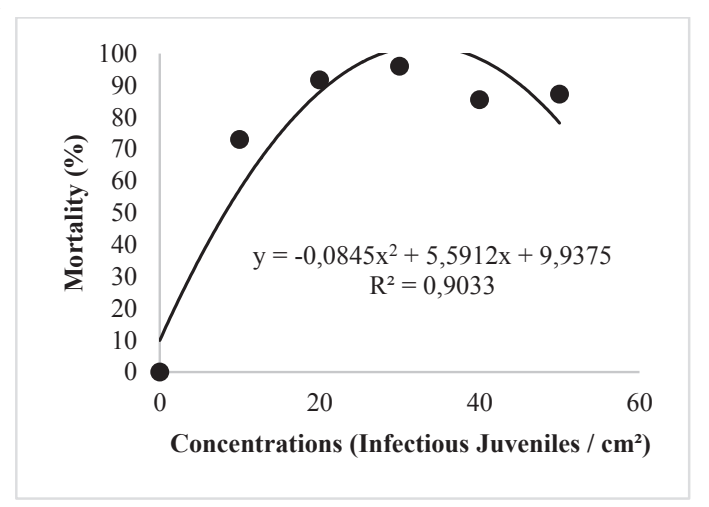

Larval mortality as a function of the concentration caused by S. carpocapsae (All) was between $79.25 \%$ and $96.0 \%$, with the highest percentage for an application of $30 \mathrm{Jls} /$ $\mathrm{cm}^{2}$. The isolate of $S$. feltiae (IBCB-n 47), as well as the $S$. carpocapsae (AII), showed a mortality percentage above $80 \%$ in all evaluated samples, varying between $83.25 \%$ and $98.0 \%$, with the highest percentage corresponding to the concentration of $50 \mathrm{JIs} / \mathrm{cm}^{2}$. When analyzing the mortality regression curve for larvae for the two isolates (Figure 2), it can be observed that at the lowest concentration (10 $\left.\mathrm{Jls} / \mathrm{cm}^{2}\right)$, both isolates showed a mortality rate greater than $79 \%$, and the response due to increased concentration was not very variable.

B

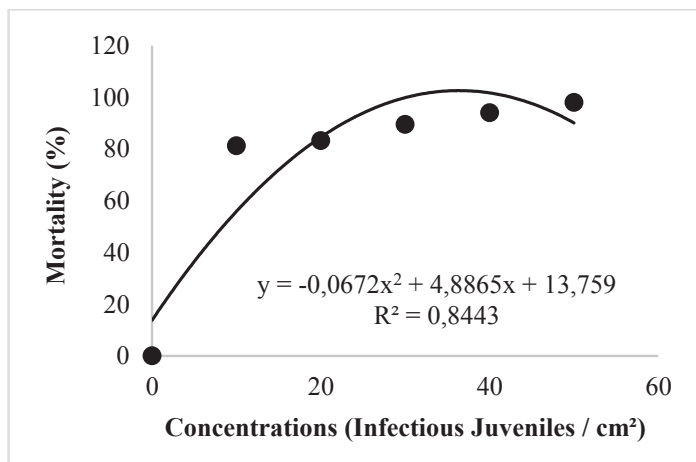

C

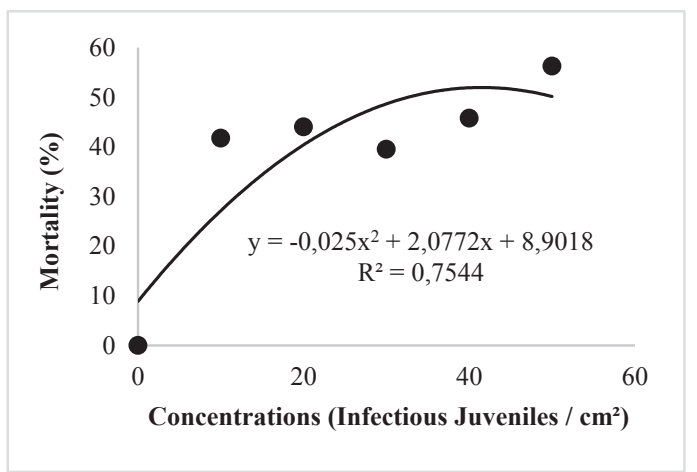

Figure 2. Mortality regression curve (\%) of Alphitobius diaperinus larvae as a function of concentrations (Jls/ $\mathrm{cm}^{2}$ ) of entomopathogenic nematodes: A) Steinernema carpocapsae (All) (Jls $\left./ \mathrm{cm}^{2}\right)$, B) Steinernema feltiae (IBCB-n 47), and C) Heterorhabditis amazonensis (UEL 07). Maximum estimated mortality: A) $102.42 \%$ with application of $33.08 \mathrm{Jls} / \mathrm{cm}^{2}$, B) $102.83 \%$ with application of $36.46 \mathrm{JIs} / \mathrm{cm}^{2}$, and C) $51.97 \%$ with application of $41.46 \mathrm{Jls} / \mathrm{cm}^{2}$. 
The UEL 07 isolate, similar to the results from the concentration test with adults, showed reduced performance when applied in the smallest concentrations. Thus, it is recommended that the largest number of Jls per area is used to ensure control of the pest.

These conclusions are based on tests done under controlled conditions. In tests undertaken under field-conditions, NEPs are likely to be subject to a series of deleterious factors, such as temperature and exposure to ammonia, in addition to having to search for the host (V. S. Alves, Moino, Santa-Cecilia, Andaló, \& Souza, 2009). Hence, these conclusions should be taken as preliminary, requiring further corroboration from field-based studies."

\section{Assessment of density and $\mathrm{pH}$}

The density of the new bed was 0.346 and that of the old bed was 0.726 . This justified the use of half the quantity of litter in treatment with old beds compared to treatment with new beds to meet a depth of $1.25 \mathrm{~cm}$ in each experimental unit.

The $\mathrm{pH}$ of the new and old beds was 7.6 and 7.5 , respectively. Thus, there was no change in the $\mathrm{pH}$ of the substrate between litter batches.

\section{Evaluation of the effect of bed on pathogenicity} and virulence of NEPS

There was no significant difference in the effect of each isolate when applied to new and old bedding. On the other hand, within each bed condition, there was a difference between the isolates (Table 4).

Table 4

Effect of new (first batch) and old (fifth batch) poultry litter on the virulence of entomopathogenic nematodes on the adults of Alphitobius diaperinus under laboratory conditions. Temperature: $25 \pm 1$ ${ }^{\circ} \mathrm{C}$, without photophase (dark)

Treatments

Steinernema feltiae (IBCB-n 47)

Steinernema carpocapsae (All)

Heterorhabditis amazonensis (UEL 08)

Control

C.V.

\section{Bed type}

New

$60.7 \pm 7.2 \mathrm{Aa}^{*}$

$58 ., 7 \pm 9.9 \mathrm{Aa}$

$20.0 \pm 6 ., 7 \mathrm{Ba}$

$0.0 \pm 0.0 \mathrm{Ba}$

36.65

* Averages followed by the same uppercase letter in the column and lowercase letter in the line do not differ from each other by Tukey's test ( $\mathrm{P} \leq 0.05)$. 
In the treatment with new bed, $H$. amazonensis (UEL 08) did not differ from the control, reaching $20 \%$ mortality. S. feltiae and $S$. carpocapsae were the most virulent, with mortality rates of $60.7 \%$ and $58.7 \%$, respectively, which did not differ from each other (Table 4).

In the treatment with old bed, all isolates differed from the control. $H$. amazonensis (UEL 08) was found to be the least virulent showing a mortality rate of $28.7 \%$, while those of the nonnative S. feltiae (IBCB-n 47) and S. carpocapsae (all) were found to be the most virulent, with average mortality values of $80 \%$ and $74.7 \%$, respectively, which did not significantly differ from each other (Table 4).

As previously mentioned, V. S. Alves et al. (2012) evaluated the isolate $S$. carpocapsae (IBCB-n 02) under laboratory conditions of 25 $\pm 1{ }^{\circ} \mathrm{C}$ and 12 hours of photophase, with the same concentration of $\mathrm{Jls} / \mathrm{cm}^{2}$ and found lower mortality (19\%) compared to results from this study (74.7\%).

The low virulence of the isolate $S$. carpocapsae (All) in the study by V. S. Alves et al. (2012) can be explained by the ambusher behavior of the nematode (Kaya \& Gaugler, 1993). In addition, in that study, the nematodes were inoculated in sterile soil at the bottom of the experimental units, the poultry bed was then deposited on the soil, and the insects were introduced on the bed. Given the distance between the soil and the bed surface where the insects were present, the nematode had less contact with the insects, which could justify the lower mortality observed. Unlike the bioassays performed in this study, none of the nematodes were inoculated directly into the bed and in direct contact with the insects.
Few studies have evaluated the effect of different batches of aviary litter on the pathogenicity and virulence of entomopathogenic nematodes. Jeffrey (2001) reported that the $\mathrm{pH}$ of the chamber varied from 6.0 to 9.0. In this study, the $\mathrm{pH}$ varied between the two batches of poultry litter, from 7.6 (new litter) to 7.5 (old litter). In the study by Kung, Gaugler and Kaya (1990), the results indicated that the $\mathrm{pH}$ between 4.0 and 6.0 was ideal for the effectiveness of $S$. carpocapsae and S. glaseri and observed that the best rates were at $\mathrm{pH} 5.1$, with $83 \%$ decrease in the host numbers. The performance was found to decrease slightly from $\mathrm{pH}$ 6.5. In our study, given the minimal change in the $\mathrm{pH}$ between new and old beds, the virulence of the nematodes was not affected.

The continuous process of poultry breeding, molting, and regrowth of feathers and recommencement of egg laying throughout the breeding cycle makes the bed microbiota very diverse. Physical variations in the bed, such as humidity, water activity, and $\mathrm{pH}$, were observed by Paganini (2004), who concluded that the higher the humidity, the greater the water activity and the higher the $\mathrm{pH}$.

Despite presenting virulence above $80 \%$ in laboratory conditions, the native isolates (UEL 07 and UEL 08) reduced performance both in the concentration test and in the interference test of the poultry litter, when compared to the two non-native isolates, suggesting that the exotic isolates have the greatest potential for use in the field. However, the use of exotic species should be avoided, as these can become a threat to native species and could also affect non-target species (Dolinski \& Moino, 2006). 
The native individuals UEL 07 and UEL 08 belong to the species $H$. amazonensis (Guide, 2019), which currently include at least six isolated species in Brazil (Andaló, Nguyen \& Moino, 2006; Barbosa-Negrisoli et al., 2010; Brida et al., 2017; Guide, 2019). Thus, it is suggested that the other isolates that were not considered in this study are also tested for their virulence and other parameters such as recommended lethal concentrations and the effect of bed conditions are determined. Further, evaluations in the field for all isolates need to be carried out. In addition, studies on the manipulation of native species are suggested, wherein improvements based on a combination of resources that may differ from already tested combinations should be explored for better performance.

\section{Conclusion}

The $H$. amazonensis UEL 07 and UEL 08 were the native isolates with the greatest potential for controlling $A$. diaperinus.

The exotic nematodes S. feltiae (IBCB-n 47) and S. carpocapsae (All) were more virulent at lower concentrations, and also when applied to different types of bedding, when compared to native $H$. amazonensis UEL 07 and UEL 08.

\section{References}

Alves, L. F. A., Rohde, C., \& Alves, V. S. (2005). Patogenicidade de Steinernema glaseri e S. carpocapsae (Nematoda: Rhabdita) contra o cascudinho, Alphitobius diaperinus (Panzer) (Coleoptera: Tenebrionidae). Neotropical Entomology, 34(1), 139-141. doi: 10.1590/S1519566X2005000100022
Alves, V. S., Moino, J. A., Santa-Cecilia, L. V. C., Andaló, V., \& Souza, G. C. (2009). Patogenicidade de nematoides entomopatogênicos a cochonilha-daraiz-do-cafeeiro Dysmicoccus texensis (Tinsley) (Hemiptera: Pseudococcidae) em laboratório. Arquivos do Instituto Biológico, 76(1), 67-73

Alves, V.S., Neves, P. M. J. O., Alves, L. F. A., Moino, A., Jr., \& Holz, N. (2012). Entomopathogenic nematodes(Rhabditida:Heterorhabditidae and Steinernematidae) screening for lesser mealworm Alphitobius diaperinus (Coleoptera: Tenebrionidae) control. Revista Colombiana de Entomologia, 38(1), 76-80.

Andaló, V., Nguyen, K., \& Moino, A., Jr. (2006). Heterorhabditis amazonensis $\mathrm{n}$. $\mathrm{sp}$. (Rhabditida: Heterorhabditidae) from Amazonas, Brazil. Nematology, 8(1), 853967. doi: 10.1163/15685410677979 9286

Axtell, R. C., \& Arends, J. J. (1990). Ecology and management of arthropod pests of poultry. Annual Review of Entomology, 35(1), 101-126. doi: 10.1146/annurev. en.35.010190.000533

Barbosa-Negrisoli, C. R. C., Garcia, M. S., Dolinski, C., Negrisoli, A. S., Jr., Bernardi, D., \& Santos, F. J. (2010). Survey of entomopathogenic nematodes (Rhabditida: Heterorhabditidae, Steinernematidae) in Rio Grande do Sul State, Brazil. Nematologia Brasileira, 34(1), 189-197.

Brida, A. L., Rosa, J. M. O., Oliveira, C.M.G., Castro, B. M. C., Serrão, J. E., Zanuncio, J. C.,... Wilcken, S. R. S. (2017). Entomopathogenic nematodes in agricultural areas in Brazil. Scientific Reports, 7(1), 45254. doi: $10.1038 /$ srep45254 
Claessen, M. E. C., Barreto, W. O., Paula, J. L, \& Duarte, M. N. (1997). Manual de métodos de análise de solo (2a ed.). Rio de Janeiro: EMBRAPA.

Del Valle, E. E., Frizzo, L. S., Malmierca, M., Zbrun, M. V., Lax, P., \& Doucet, M. E. (2016). Biological control of Alphitobius diaperinus with Steinernema rarum CUL and Heterorhabditis bacteriophora SMC and feasibility of application in rice hull. Journal of Pest Science, 89(1), 161-170. doi: 10.1007/s10340-015-0669-8

Despins, J. L., \& Axtell, R. C. (1995). Feeding behavior and growth of broiler chicks fed larvae of the darkling beetle, Alphitobius diaperinus. Poultry Science, 74(2), 331336. doi: 10.3382/ps.0740331

Dolinski, C., \& Moino, A., Jr. (2006). Utilização de nematóides entomopatogênicos nativos ou exóticos: o perigo das introduções. Nematologia Brasileira, 30(1), 139-149.

Ferreira, D. F. (2011). Sisvar: um sistema computacional de análise estatística. Ciência e Agrotecnologia, 35(6), 10391042. doi: 10.1590/S1413-70542011000 600001

Forst, S., \& Clarke, D. (2002). Bacterianematode symbiosis. In R. Gaugler (Ed.), Entomopathogenic nematology (pp. 5777). New York, NY: CABI Publishing.

Fuga, C. A. G., Fernandes, R. H., \& Lopes, E. A. (2012). Nematoides entomopatogênicos. Revista Trópica: Ciências Agrárias e Biológicas, 6(3), 56-75. doi: 10.0000/rtcab. v6i3.900

Gaugler, R., Wang, Y., \& Campbell, J. F. (1994). AggressiveandevasivebehaviorsinPopillia japonica (Coleoptera: Scarabaeidae) larvae: defenses against entomopathogenic nematode attack. Journal of Invertebrate Pathology, 64(1), 193-199. doi: 10.1016/ S0022-2011(94)90150-3
Geden, C. J., Axtell, R. C., \& Brooks, W. M. (1985). Susceptibility of the lesser mealworm, Alphitobius diaperinus (Coleoptera: Tenebrionidae) to the entomogenous nematodes Steinernema feltiae, S. glaseri (Steinernematidae) and Heterorhabditis heliothidis (Heterorhabditidae). Journal of Entomological Science, 20(3), 331-339. doi: 10.18474/0749-8004-20.3.331

Grewal, P. S., Nardo, E. A. B., \& Aguillera, M. M. (2001). Entomopathogenic nematodes: potential for exploration and use in South America. Neotropical Entomology, 30(2), 191-205. doi: 10.1590/S1519-566 X2001000200001.

Guide, B. A. (2019). Identificação e aspectos biológicos do nematoide entomopatogênico Heterorhabditis amazonenses Isolado. Tese de doutorado, Programa Pós-Graduação em Agronomia, Universidade Estadual de Londrina, Londrina, PR, Brasil.

Guide, B. A., Alves, V. S., Fernandes, T. A. P., Ferreira, F. P., \& Neves, P. M. O. J. (2016). Glycerol as a cryoprotectant agent to the entomopathogenic nematodes Heterorhabditis spp. and Steinernema spp. Semina: Ciências Agrárias, 37(5), 3017-3026. doi: 10.5433/1679-0359

Japp, A. K., Bicho, C. L., \& Silva, A. V. F. (2008). Interferência no ganho de peso de frangos de corte alimentados com cascudinhos Alphitobius diaperinus Panzer (Coleoptera: Tenebrionidae). Revista Brasileira de Ciência Avícola, 10(1), 170.

Japp, A. K., Bicho, C. L., \& Silva, A. V. F. (2010). Importância e medidas de controle para Alphitobius diaperinus em aviários. Ciência Rural, 40(7), 1668-1673. doi: 10.1590/S0103-84782010005000114

Jeffrey, J. S. (2001). Inactivation of bactéria in stacked poultry litter. Davis: University of California. (USPEA Final Report). 
Kaya, H. K., \& Gaugler, R. (1993). Entomopathogenic nematodes. Annual Review of Entomology, 38(1), 181-206. doi: 10.1146/annurev.en.38.010193.001145

Kung, S., Gaugler, R., \& Kaya, H. K. (1990). Influence of soil $\mathrm{pH}$ and oxygen on persistence of Steinernema spp. Journal of Nematology, 22(4), 440-445.

Lewis, E. E., Campbell, J., Griffin, C., Kaya, H., \& Peters, A. (2006). Behavioral ecology of entomopathogenic nematodes. Biological Control, 38(1), 66-79. doi: 10.1016/j. biocontrol.2005.11.007

Li, X., Liu, Q., Lewis, E. E., \& Tarasco, E. (2016). Activity changes of antioxidant and detoxifying enzymes in Tenebrio molitor (Coleoptera: Tenebrionidae) larvae infected by the entomopathogenic nematode Heterorhabditis beicherriana (Rhabditida: Heterorhabditidae). Parasitology Research, 115(12), 44854494. doi: 10.1007/s00436-016-5235-7

Molina, J. P., \& Lopez, J. C. (2001). Desplazamiento y parasitismo de los entomonematodos Steinernema feltiae (Rhabditida: Steinernematidae) y Heterorhabditis bacteriophora (Rhabditida: Heterorhabditidae) hacia frutos infestados con la broca del café Hypothenemus hampei (Coleoptera: Scolytidae). Revista Colombiana de Entomología, 28(1), 145-151.

Nguyen, K. B., Ginarte, C. M. A., Leite, L. G., Santos, J. M. dos, \& Harakava, R. (2010). Steinernema brazilense n. sp. (Rhabditida: Steinernematidae), a new entomopathogenic nematode from Mato Grosso, Brazil. Journal of Invertebrate Pathology, 103(1), 8-20. doi: 10.1016/j. jip.2009.09.004
Paganini, F. J. (2004). Manejo da cama. In A. Mendes, I. A. Naas, M. Macari (Eds.), Produção de frangos de corte (pp. 107-116). Campinas: FACTA. doi: 10.25061/2527-2675/ReBraM/2014. v17i2.21

Rahoo, A. M., Mukhtar, T., Gowen, S. R., Rahoo, R. K., \& Abro, S. I. (2017). Reproductive potential and host searching ability of entomopathogenic nematode, Steinernema feltiae. Pakistan Journal of Zoology, 49(1), doi: 10.17582/journal. pjz/2017.49.1.229.234

Rohde, C., Alves, L. F. A., Neves, P. M. O. J., Alves, S. B., Silva, E. R. L., \& Almeida, J. E. M. (2006). Seleção de isolados de Beauveria bassiana (Bals.) Vuill. e Metarhizium anisopliae (Metsch.) Sorok. contra o cascudinho Alphitobius diaperinus (Panzer) (Coleoptera: Tenebrionidae). Neotropical Entomology, 35(2), 231-240. doi: 10.1590/ S1519-566X2006000200012

Román, J., \& Figueroa, W. (1994). Steinernema puertoricensis n. $\mathrm{sp}$. (Rhabditida: Steinernematidae), a new entomopathogenic nematode from Puerto Rico. The Journal of Agriculture of the University of Puerto Rico, 78(3-4), 167175. doi: 10.46429/jaupr.v78i3-4.4285

Szalanski, A. L., Palmer, T. W., Mckay, T., \& Steelman, C. D. (2004). Infectivity of Steinernema spp. (Nematoda: Steinernematidae) to adult litter beetles, Alphitobius diaperinus (Coleoptera: Tenebrionidae) in the laboratory. Biocontrol Science and Technology, 14(1), 81-85. doi: 10.1080/0958315031000151729

Vaughan, J. A., Turner, E. C., Jr., \& Ruszler, P. L. (1984). Infestation and damage of poultry house insulation by the lesser mealworm, Alphitobius diaperinus (Panzer). Poultry Science, 63(1), 1094-1100. doi: 10.33 82/ ps.0631094 
